\title{
Divergent selection for secondary metabolites between wild populations of Brassica oleracea and its implications for plant-herbivore interactions
}

\author{
R. MITHEN*, A. F. RAYBOULD \& \& A. GIAMOUSTARIS \\ Brassica and Oilseeds Research Department, John Innes Centre, Colney Lane, Norwich NR4 7UH and †Institute of \\ Terrestrial Ecology, Furzebrook Research Station, Wareham, Dorset BH20 5AS, U.K.
}

\begin{abstract}
Significant differences occur in the levels and types of aliphatic glucosinolates in leaves of plants of four Brassica oleracea populations in Dorset. Plants in grassland at St Aldhelm's Head and Winspit have high levels of 3-butenyl glucosinolate, whereas plants of an adjacent population growing on and along the top of cliffs at Kimmeridge have low levels of 2-hydroxy3-butenyl, 2-propenyl and methylsulphinylalkyl glucosinolates. Plants growing in a variable habitat at Worbarrow Tout have intermediate levels. The differences in occurrence of individual glucosinolates result from allelic variation at four loci. The level of total aliphatic glucosinolates is under more complex genetic control, but is shown to be highly heritable. Allele frequencies at isozyme loci indicate that genetic variation for glucosinolate production is unlikely to have arisen or to be maintained by founder effects or genetic drift. It is suggested that there is selection for high levels of butenyl glucosinolates at St Aldhelm's Head and Winspit because of grazing by generalist herbivores, whereas there is selection for low levels of 2-hydroxy-3-butenyl and other non-butenyl aliphatic glucosinolates at Kimmeridge because of two factors. First, plants effectively escape from generalist herbivores because of physical aspects of the habitat and association with other plant species which provide physical and chemical defences. Thus there is selection for individuals which do not carry the hypothetical metabolic costs of glucosinolate biosynthesis. Secondly, herbivory by specialist cruciferous insects at Kimmeridge, which is enhanced because of the local abundance of $B$. nigra, selects for individuals which have low levels of 2-hydroxy-3-butenyl glucosinolates.
\end{abstract}

Keywords: Brassica, coevolution, $F$-statistics, generalist herbivores, glucosinolates, specialist herbivores.

\section{Introduction}

Plant secondary metabolites are widely regarded as being an important component of defence mechanisms against herbivory. Variation in secondary metabolites in natural plant populations may therefore indicate current and historical patterns of herbivore activity, and provide insights into the selective forces acting within and between plant populations.

While secondary metabolites may provide effective defence against generalist herbivores, investment in these metabolites incurs two major costs. First, it is likely that there are significant metabolic costs associated with the biosynthesis and mainte-

\footnotetext{
${ }^{*}$ Correspondence.
}

nance of secondary metabolites and associated specialized structures. Secondly, many secondary metabolites attract and stimulate feeding behaviour of insect herbivores which have become specialists on taxa which contain the particular metabolite. There are, therefore, contrasting selection pressures on secondary metabolism, and the metabolite composition will be a result of the interaction of these different selective pressures and random genetic effects. Insufficient understanding of the genetic basis of secondary metabolite biosynthesis has limited studies on the ecological genetics of secondary metabolism.

Glucosinolates are secondary metabolites which occur in the Capparales and a few unrelated taxa. The molecule comprises a common glycone moiety 
Fig. 1 Biochemical genetics of aliphatic glucosinolates. Aliphatic glucosinolates such as 3-butenyl glucosinolate (a) are hydrolysed to the corresponding isothiocyanate (b). Addition of a $\beta$-hydroxy group (c) results in spontaneous cyclization of the isothiocyanate to 5-vinyloxazolidine-2-thione (d), which is nonvolatile. The side chain structure is controlled by alleles at two loci which regulate side chain length (pro and elong) and three loci which regulate side chain structure (sulp, alk and $o h$ ).
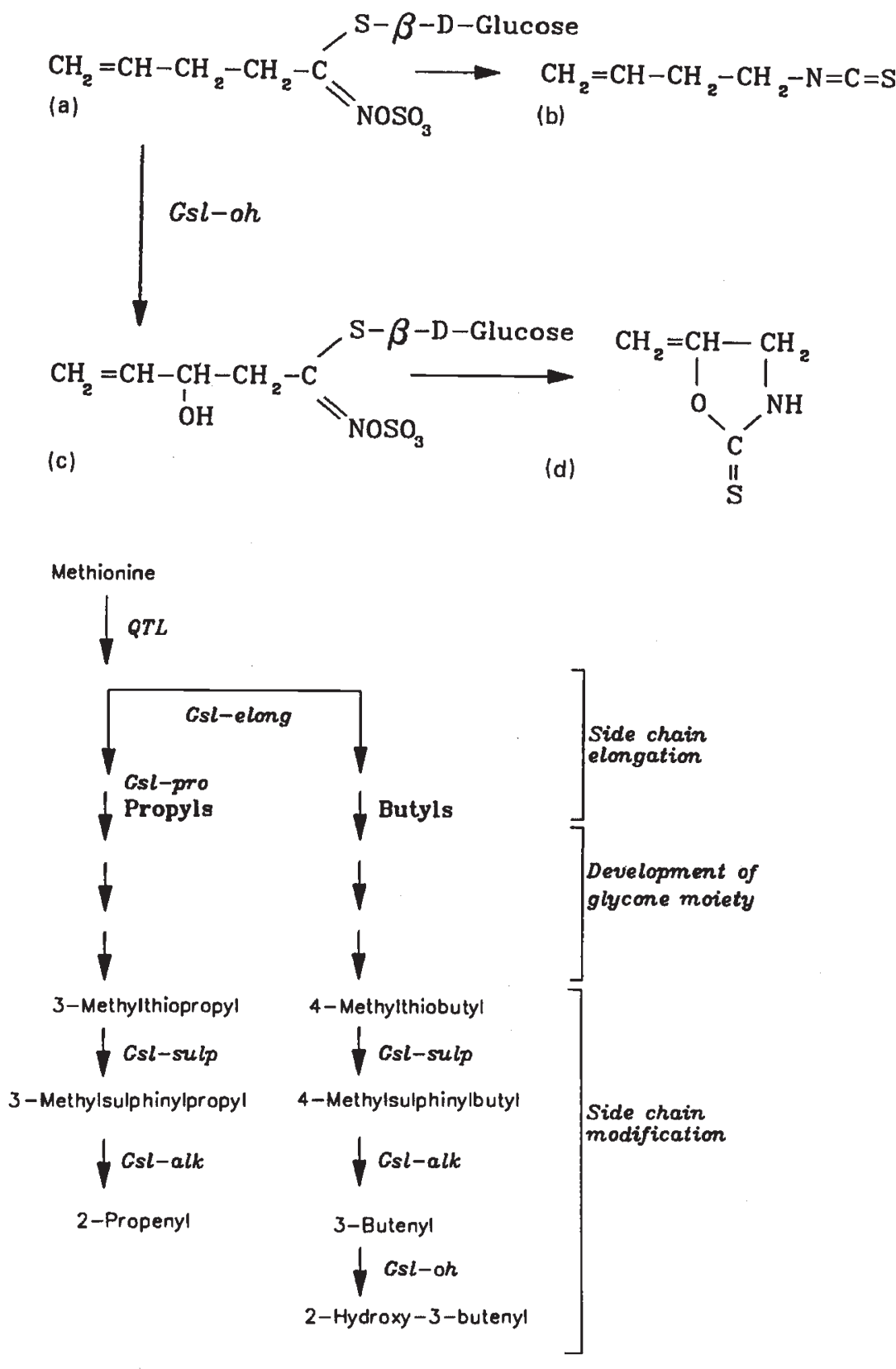

and a variable aglycone side chain, which is derived from amino acids (Fig. 1). Glucosinolates with an aliphatic side chain are derived from methionine, those with a indole side chain from tryptophan and those with an aromatic side chain from phenylalanine. Aliphatic glucosinolates are the most abundant class of glucosinolates in leaves of Brassica and certain other cruciferous genera. Following tissue damage, aliphatic glucosinolates undergo hydrolysis catalysed by the endogenous enzyme myrosinase and produce an array of products, of which isothiocyanates ('mustard oils') are the most prominent under ambient conditions of temperature and $\mathrm{pH}$. If the aliphatic side chain contains a $\beta$-hydroxy group, the isothiocyanate spontaneously cyclizes to produce the corresponding oxazolidine-2-thione (Fig. 1).

Glucosinolates have been shown to mediate herbivore interactions. They reduce palatability of leaf tissue to generalist herbivores, such as birds, molluscs and generalist insects (Chew, 1988; Glen et al., 1990; Louda \& Mole, 1991; Mithen, 1992, Giamoustaris \& Mithen, 1995), and attract and stimulate feeding and egg laying by insects which feed specifically on crucifers, such as flea beetles 
(Psylliodes spp. and Phyllotreta spp.), Pieris spp., Delia spp, Brevycorne brassicae, Dasineura brassicae and Ceutoryhncus assimilis (Hicks, 1974; Chew, 1988; Louda \& Mole, 1991; Simmonds et al., 1994; Giamoustaris \& Mithen, 1995). Both the total level of aliphatic glucosinolates and the side chain structure are important in mediating these interactions. Several recent studies have begun to elucidate the genetic basis of biosynthesis of aliphatic glucosinolates (Magrath et al., 1993, 1994; Parkin et al., 1994; Mithen et al., 1995) and have shown that variation in side chain structure is under simple genetic control (Fig.1). Geographical and ecological variation in aliphatic glucosinolate composition has been described in Brassica (Mithen et al., 1987), Cakile edentula (Rodman, 1980), Arabidopsis thaliana (Bano, 1993; Mithen et al., 1995) and Cardamine cordifolia (Rodman \& Chew, 1980).

Wild members of the Brassica oleracea $n=9$ species complex occur on maritime cliffs of southern and western Europe. Previous preliminary studies have shown that there is considerable variation in the types of glucosinolates between taxa (Mithen et $a l ., 1987)$. In the United Kingdom, wild forms of $B$. oleracea, which are not thought to be introductions or recent escapes from domestication, occur on the coasts of Kent, Dorset, Devon, Cornwall, Glamorgan and Gwynedd (Snogerup et al., 1990). The demography and genetic structure of wild $B$. oleracea populations have received little attention. Individual plants may be up to 20 years old. Each year, between one third and a half of the individuals in a population may flower during the summer months and seedlings are found in autumn (Mitchell \& Richards, 1979). Casual observation suggests that seedling establishment is a rare event, although no detailed data are available. As an initial study into herbivory and its consequences for the genetic structure of wild Brassica populations, we have characterized the glucosinolate profiles and contents of four populations in an $11 \mathrm{~km}$ stretch of coastline in Dorset (Fig. 2) and compared this variation with that at isozyme loci.

\section{Materials and methods}

\section{Plant habitats and sampling sites}

Plants were sampled from four populations (Fig. 2). At Kimmeridge, B. oleracea plants occur on and along the top of shale cliffs. The plant community on the cliff face has few component species. Daucus carota, Silene maritime and Crithmum maritimum are frequent, but few other species are observed in significant numbers. Brassica nigra is common in places, particularly on the western cliff face of Kimmeridge Bay. On the top of the cliff between Kimmeridge Bay and Rope Lake Head B. nigra, D. carota and Rubus are abundant and occur within and around groups of $B$. oleracea plants. Rumex crispus, Plantago maritima, Hordeum mureum and Dactylus glomerata also occur in the plant community. Otherwise, the vegetation is sparse. At St. Aldhelm's Head, B. oleracea plants are found mainly in grassland. $B$. nigra occurs infrequently at St Aldhelm's sites A and B, and is absent from sites $\mathrm{C}$ and $\mathrm{D}$. The plant community at Winspit is typical of grazed grassland, with several dicotyledonous species including Bellis perennis, Anthyllis vulneraria, Echium vulgare and Trifolium repens. Brassica oleracea on Worbarrow Tout grows in two distinct habitats. First, plants are found on top of the small peninsular in relatively long grassland similar to St Aldhelm's Head sites A and B. A group of plants occurs in a patch of Rubus

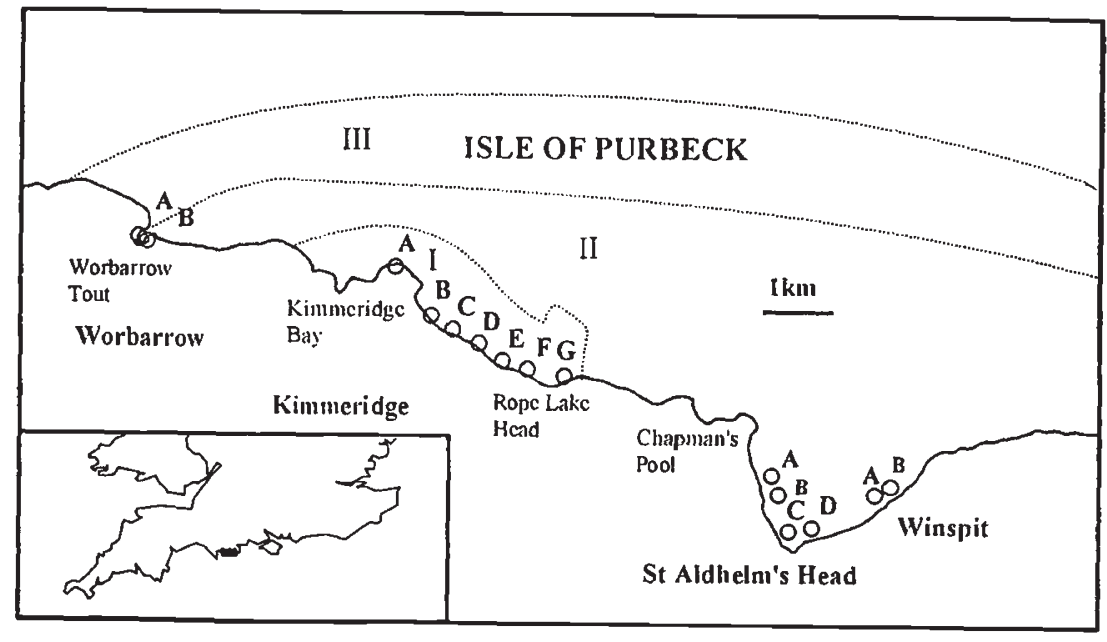

Fig. 2 Distribution of populations, collecting sites and soil types. (I) Slowly permeable seasonally waterlogged clayey soil over Jurassic and Cretaceous clay. (II) Shallow well-drained brashy calcareous clayey soils over limestone. (III) Slowly permeable seasonally waterlogged fine loamy over clayey soils. 
while other plants are found dispersed in the grass. Secondly, plants are found on the steep west face of the Tout growing in a wet clay soil in a sparse plant community similar to that found on the cliffs of Kimmeridge Bay.

The differences in the composition of the plant communities may result partially from the variation in the underlying geology and soils (Fig. 2). The population at Kimmeridge is found on shale cliffs overlaid with a slowly permeable clay soil which is seasonally waterlogged. In contrast, the populations at St Aldhelm's Head and Winspit occur on limestone overlaid with shallow well-drained calcareous soils. Worbarrow Tout lies on the junction of the geology and soils found at St Aldhelm's Head with a third type comprising a clay/loam soil which becomes seasonally waterlogged similar to the soil at Kimmeridge.

Several insect herbivores which are specialist feeders on crucifers occur in the populations. Flea beetles are abundant, particularly on $B$. nigra, but are also observed feeding on $B$. oleracea. Brevicoryne brassicae (cabbage aphid) is also abundant, in addition to its parasitoids, and was found on vegetative and reproductive tissues. Pieris rapae (small white butterfly) adults and larvae, Dasineura brassicae (pod midge) and Ceutorhynchus assimilis (seed weevil) are also observed. Snails are abundant on $B$. oleracea plants, although relatively infrequent on plants growing on the cliff face at Kimmeridge Bay. The short grass at Winspit suggests that it is intensely grazed by rabbits, and droppings are observed.

\section{Glucosinolate analyses}

Leaves from 165 plants from the four populations were collected. Two sites were sampled at each of Worbarrow and Winspit, four at St Aldhelm's Head and seven at Kimmeridge (Fig. 2, Table 1). From each plant between 5 and 10 leaves were removed and immediately frozen in solid $\mathrm{CO}_{2}$ in an insulated box. A range of leaf sizes and ages was collected. Leaves which had large fungal lesions or were clearly damaged were not chosen. Three samples of $B$. nigra from Kimmeridge $\mathrm{D}$ were also collected in the same manner. Samples were collected on three different dates, 1 June (Kimmeridge A, St Aldhelm's $C$ and $D$ and Winspit $A$ and $B$ ), 2 August (Worbarrow $A$ and $B$, Kimmeridge $A$ and $B$ ) and 6 December (Kimmeridge B-G, St Aldhelm's A and B). The leaf material was transferred to a freeze drier and the dried tissue ground into a coarse powder. Glucosinolates from a $0.1 \mathrm{~g}$ sample of the ground tissue were extracted in hot methanol, converted to desul-
Table 1 Total aliphatic glucosinolate content (mean \pm SE) of leaves of Brassica plants at the four Devon sites

\begin{tabular}{lrrc}
\hline Site & & & $\begin{array}{c}\text { Aliphatic glucosinolates } \\
(\mu \text { mol/g dry wt })\end{array}$ \\
\hline B. oleracea & & $n$ & \\
Worbarrow & A & 10 & $56.2 \pm 6.76 \mathrm{c}$ \\
Kimmeridge & B & 8 & $19.3 \pm 3.42 \mathrm{~b}$ \\
& A & 27 & $8.4 \pm 0.97 \mathrm{a}$ \\
& B & 18 & $6.0 \pm 0.78 \mathrm{a}$ \\
& C & 10 & $10.8 \pm 1.61 \mathrm{a}$ \\
& D & 4 & $9.2 \pm 2.25 \mathrm{a}$ \\
St Aldhelm's Head & E & 4 & $5.6 \pm 1.13 \mathrm{a}$ \\
& F & 5 & $9.8 \pm 1.85 \mathrm{a}$ \\
& B & 5 & $23.9 \pm 4.57 \mathrm{~b}$ \\
Winspit & B & 7 & $78.8 \pm 6.18 \mathrm{~d} \mathrm{f}$ \\
& D & 10 & $79.3 \pm 7.05 \mathrm{~d} \mathrm{f}$ \\
B. nigra & A & 11 & $89.4 \pm 5.48 \mathrm{c}$ \\
Kimmeridge & B & 7 & $135.1 \pm 11.70 \mathrm{~d}$ \\
\hline
\end{tabular}

Values followed by the same letter are not significantly different from each other $(t$-test, $P>0.05)$.

phoglucosinolates and analysed by HPLC as described by Magrath et al. (1994).

Seeds from several plants at Worbarrow A and B, Kimmeridge A, St Aldhelm's Head C and Winspit A were collected. Ten plants from each accession were grown in a glasshouse under standard conditions in John Innes no. 1 compost. When the plants had five true leaves, the leaves from each family were harvested and bulked together. Glucosinolates were extracted and analysed from the leaves as described above.

\section{Isozymes}

Plants for isozyme analysis were sampled from Winspit, St Aldhelm's Head and Kimmeridge. No collections were made from Worbarrow as access is restricted and sampling could not be undertaken during the short period when good quality extracts can be made (see below). At both Winspit and St Aldhelm's Head 120 samples were taken from the full range of subpopulations indicated above. At Kimmeridge 60 plants were collected from sites BE.

Isozymes were extracted from $500 \mathrm{mg}$ of fresh young tissue in $2 \mathrm{~mL}$ of buffer $(0.1 \mathrm{M}$ Tris $-\mathrm{HCl}, \mathrm{pH}$ 
7.0, 4 per cent polyvinylpyrrolidone, 0.1 per cent mercaptoethanol and 2 per cent caffeine) by the method of Raybould et al. (1991). Satisfactory results were only obtained from young, actively growing tissue collected following periods of wet weather in the spring and early summer. At other times activity and/or resolution of isozymes was poor. Fifteen isozyme systems were assayed on both the acrylamide and starch gel systems described by Raybould et al. (1991). Of these, only acid phosphatase $(\mathrm{AcPH})$, phosphoglucose isomerase (PGI) and shikimic acid dehydrogenase $(\mathrm{ShDH})$ gave consistently interpretable results, each providing a single polymorphic locus. Attempts to improve the resolution of other systems by modifications to the extraction buffer to reduce the interfering action of polyphenol oxidase (Wendel \& Weeden, 1989) were unsuccessful.

\section{Analysis of genetic structure}

Isozyme data were analysed by FSTAT (Goudet, 1995), a program which calculates unbiased estimators of Wright's (1943) $F$-statistics (Weir \& Cockerham, 1984). $F_{\text {Is }}$ was derived for each population and used as the measure of inbreeding $(F)$ when calculating the allele and genotype frequencies at the glucosinolate loci (as heterozygotes are not possible to identify unequivocally). Frequencies were estimated from Wright's (1921) formulae which correct Hardy-Weinberg proportions for inbreeding. If the null allele $(-)$ frequency is $q$ and the functional allele $(+)$ frequency is $p=1-q$, then genotype proportions are given by:

$$
\begin{aligned}
& ++p^{2}(1-F)+p F \\
& +-2 p q(1-F) \\
& --q^{2}(1-F)+q F .
\end{aligned}
$$

Hence the proportion of null homozygotes and an estimate of $F$ allow estimation of genotype and allele frequencies. Genotype proportions were converted into numbers of plants for use with FSTAT to derive $F_{\mathrm{ST}}$ estimates.

$F_{\text {ST }}$ values were calculated for each locus individually over all populations. Standard errors for these individual locus values were obtained by jackknifing over populations. $F_{\mathrm{ST}}$ values were tested for significance using a $t$-test with $n-1$ degrees of freedom, where $n$ is the number of populations. Estimates of $F_{\mathrm{ST}}$ for all isozyme loci $\left(F_{\mathrm{ST.I}}\right)$ and all glucosinolate loci $\left(F_{\mathrm{ST.G}}\right)$ were also made over all populations. Standard errors (SE.F $F_{\text {ST.I }}$ and SE.F. $\left.F_{\text {ST.G }}\right)$ were obtained by jackknifing over loci. $F_{\mathrm{ST}}$ values were tested for significance by a $t$-test with $n-1$ degrees of freedom, where $n$ is the number of loci. The difference between the two $F_{\mathrm{ST}}$ values was tested using a $t$ test where

$t=\left(F_{\mathrm{ST} . \mathrm{I}}-F_{\mathrm{ST} . \mathrm{G}}\right) / \sqrt{ }\left(\mathrm{SE} . F_{\mathrm{ST} . \mathrm{I}}^{2}+\mathrm{SE} . F_{\mathrm{ST} . \mathrm{G}}^{2}\right)$

with $n_{\mathrm{d}}$ degrees of freedom where

$$
\begin{aligned}
& n_{\mathrm{d}}=\left(\mathrm{SE} . F_{\mathrm{ST} . \mathrm{I}}^{2}+\mathrm{SE} . F_{\mathrm{ST} . \mathrm{G}}^{2}\right)^{2} / \\
& \quad\left(\left\{\mathrm{SE} . F_{\mathrm{ST} . \mathrm{I}}^{4} / n_{\mathrm{I}}-1\right\}+\left\{\mathrm{SE} . \mathrm{F}_{\mathrm{ST} . \mathrm{G}}^{4} / n_{\mathrm{G}}-1\right\}\right)
\end{aligned}
$$

with $n_{\mathrm{I}}$ and $n_{\mathrm{G}}$ being the number of loci in the estimates of $F_{\mathrm{ST}}$ across the isozyme and glucosinolate loci, respectively (Bailey, 1959).

Pairwise $F_{\text {ST }}$ values between each population at both isozyme and glucosinolate loci were also obtained and the difference tested in the same way as for the over all population estimates.

\section{Results}

There were no significant differences in the levels of aliphatic glucosinolates in leaves of plants collected from the same site at different harvest times, but there were significant differences between sites (Table 1). At Worbarrow, plants collected in grassland on top of the small peninsular (site A) have significantly greater levels of glucosinolates than plants collected from the cliff face (site B). There were no differences between the Kimmeridge sites except for the most easterly site which had significantly higher levels. There were no differences between the St Aldhelm's Head sites A, B, D and Winspit A. St Aldhelm's Head C had lower levels and Winspit B had higher levels. Plants from all the St Aldhelm's and Winspit sites had higher amounts of aliphatic glucosinolates than those from Kimmeridge. Brassica nigra collected from Kimmeridge site $\mathrm{D}$ had high levels of aliphatic glucosinolates, similar to B. oleracea plants from St Aldhelm's Head (Table 1).

There were also differences in the occurrence of individual aliphatic glucosinolates (Fig. 3, Table 2). All the plants from St Aldhelm's and Winspit had predominantly butenyl glucosinolate. Twenty-one per cent of the plants also had low levels of propenyl glucosinolates $(<16$ per cent of total aliphatic glucosinolates) and two plants (one from site $A$ and one from site B) had 2-hydroxy-3-butenyl glucosinolate (53 per cent and 58 per cent hydroxylation of butenyl glucosinolate, respectively). Plants from Worbarrow and the majority of plants from Kimmeridge had one of two profiles, either 2-hydroxy-3-butenyl, 2-propenyl and 3-butenyl glucosinolates, or these glucosinolates with the addition of 3-methylsulphi- 

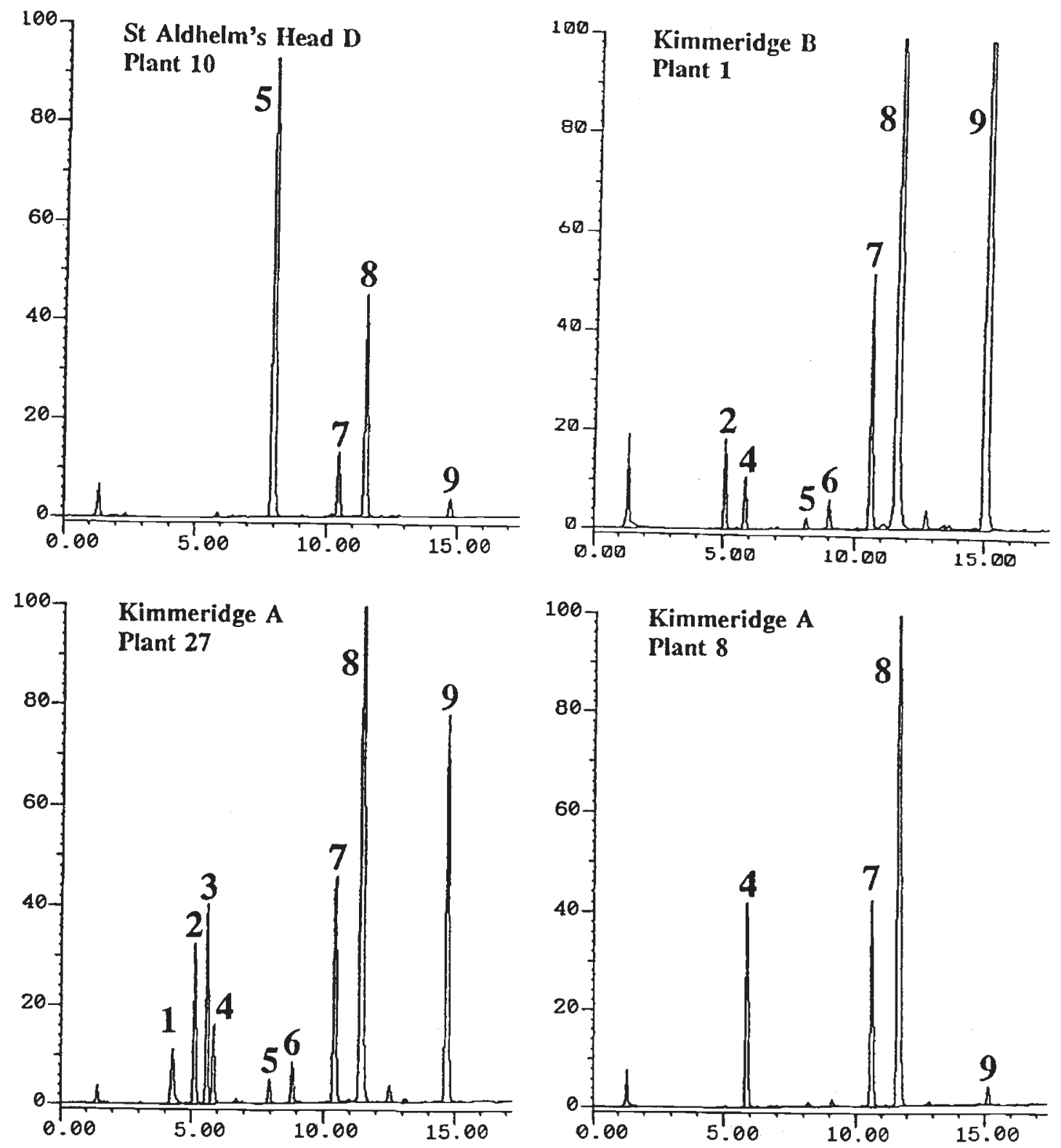

Fig. 3 HPLC chromatograms of desulphoglucosinolates. 1, 3-methylsulphinylpropyl; 2, 2-hydroxy-3-butenyl; 3, 4-methylsulphinylbutyl; 4, 2-propenyl; 5, 3-butenyl; 6, 3-methylthiopropyl; 7, benzyl (internal standard); 8, 3-indolylmethyl; 9, 1-methoxy-3-indolylmethyl.

nylpropyl and 4-methylsulphinylbutyl glucosinolate (Table 2). Two plants from Kimmeridge lacked butyl derivatives.

The occurrence of these glucosinolates can be interpreted as being the result of variation in allele frequencies at four loci, two regulating side chain length (Gsl-pro and Gsl-elong) and two regulating side chain structure (Gsl-alk and Gsl-oh) (Fig.1, Table 2). The percentage hydroxylation of butenyl glucosinolates because of the action of the functional allele at the Gsl-oh locus did not vary signifi- cantly between any of the Worbarrow or Kimmeridge populations sampled in August or December $($ mean $=86.7 \pm 0.97$ ) or when cultivated in the glasshouse $(81.2 \pm 1.51)$. The sample collected from Kimmeridge $A$ in June had significantly less hydroxylation $\quad(54.7 \pm 2.94, \quad P<0.01) \quad$ suggesting seasonal changes in enzyme activity. The differences in both total and individual aliphatic glucosinolates result in a reduction in the absolute level of butenyl glucosinolate in plants at Kimmeridge and Worbarrow compared to those at St Aldhelm's Head and 
Table 2 Frequency of aliphatic glucosinolate phenotypes in Brassica oleracea at the four Devon sites

\begin{tabular}{|c|c|c|c|c|c|c|c|c|}
\hline \multirow[b]{2}{*}{ Phenotype* } & \multicolumn{4}{|c|}{ Genotypes } & \multicolumn{4}{|c|}{ Frequency } \\
\hline & pro & elong & alk & oh & $\begin{array}{c}\text { Worbarrow } \\
n=18\end{array}$ & $\begin{array}{c}\text { Kimmeridge } \\
n=73\end{array}$ & $\begin{array}{c}\text { St Aldhelm's } \\
n=33\end{array}$ & $\begin{array}{l}\text { Winspit } \\
n=18\end{array}$ \\
\hline 2-Propenyl & + & - & + & & 0 & 0.07 & 0 & 0 \\
\hline 3-Butenyl & - & + & + & - & 0 & 0 & 0.79 & 0.61 \\
\hline $\begin{array}{l}\text { 2-Propenyl } \\
\text { 3-Butenyl }\end{array}$ & + & + & + & - & 0 & 0 & 0.15 & 0.39 \\
\hline $\begin{array}{l}\text { 3-Butenyl } \\
\text { 2-Hydroxy-3-butenyl }\end{array}$ & - & + & + & + & 0 & 0 & 0.03 & 0 \\
\hline $\begin{array}{l}\text { 2-Propenyl } \\
\text { 3-Butenyl } \\
\text { 2-Hydroxy-3-butenyl }\end{array}$ & + & + & + & + & 0.61 & 0.53 & 0.03 & 0 \\
\hline $\begin{array}{l}\text { 2-Propenyl } \\
\text { 3-Methylsulphinylpropyl }\end{array}$ & + & - & - & & 0 & 0.01 & 0 & 0 \\
\hline $\begin{array}{l}\text { 2-Propenyl } \\
\text { 3-Butenyl } \\
\text { 2-Hydroxy-3-butenyl } \\
\text { 3-Methylsulphinylpropyl } \\
\text { 4-Methylsulphinylbutyl }\end{array}$ & + & + & - & + & 0.39 & 0.39 & 0 & 0 \\
\hline
\end{tabular}

*See Fig. 3.

+ Indicates the presence of one or two functional alleles at the relevant locus.

The occurrence of + or - alleles at the $o h$ locus can only be determined if a + allele at the elong locus is present.

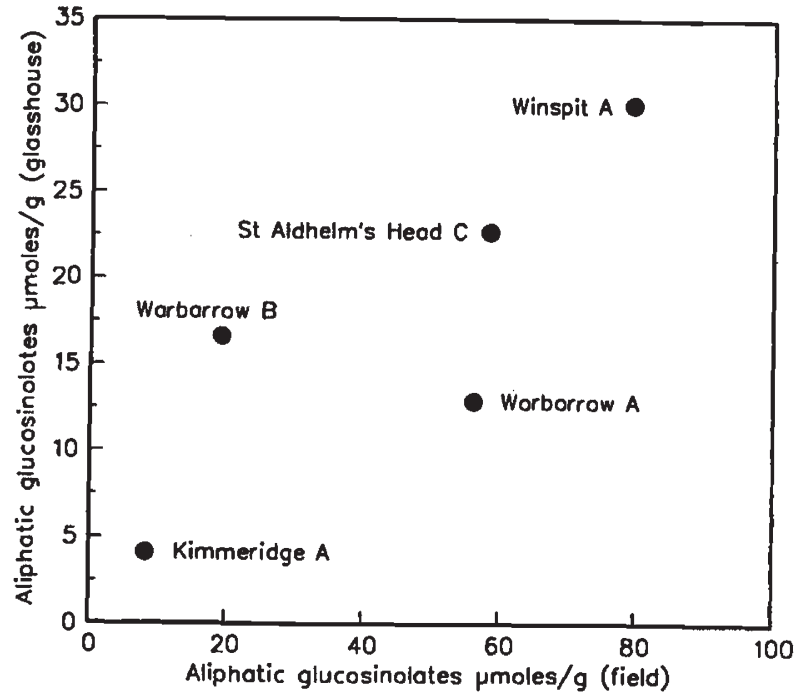

Fig. 4 Relationship between the level of aliphatic glucosinolates in field-collected leaves of Brassica oleracea and the level in bulk samples of leaves of progeny grown under identical condition in a glasshouse.

Winspit. Brassica nigra possessed only propenyl glucosinolate.

To investigate whether the differences in aliphatic glucosinolate content resulted from environmental or genetic factors, plants from seed collected from individuals at different sites were grown under controlled conditions. There was a correlation between the levels of aliphatic glucosinolates in field-collected leaves and in leaves of glasshouse-grown plants, despite the absolute level being lower in glasshouse-grown material ( $r=0.83$, Fig. 4). However, the levels in glasshouse-grown plants from the two collecting sites at Worbarrow were not closely correlated with the levels found in field-collected leaves of the parental plants. The presence and ratio of individual glucosinolates were similar to those found in the parental field-collected leaves.

The levels of indole glucosinolates were also analysed in the leaf material. Leaves collected in June had lower levels of indole glucosinolates than leaves collected in August or December (Table 3). There were no consistent differences in the levels of indole glucosinolates between the four populations. Leaves from St Aldhelm's site C had low levels and those from Kimmeridge site D had high levels. When grown in the glasshouse, there were no significant differences in the levels of indole glucosinolates between plants from any of the five sites from the four populations investigated (Table 3). There- 
Table 3 Levels of indolyl glucosinolates (mean \pm SE) in leaves of Brassica oleracea plants under different harvest conditions

\begin{tabular}{|c|c|c|c|c|c|}
\hline \multirow[b]{2}{*}{ Site } & \multicolumn{3}{|c|}{ Indolyl glucosinolates ( $\mu \mathrm{mol} / \mathrm{g}$ dry wt) } & \multirow[b]{2}{*}{$\begin{array}{c}\text { Harvest } 3 \\
6 \text { December }\end{array}$} & \multirow[b]{2}{*}{ Glasshouse-grown plants } \\
\hline & & $\begin{array}{l}\text { Harvest } 1 \\
1 \text { June }\end{array}$ & $\begin{array}{l}\text { Harvest } 2 \\
2 \text { August }\end{array}$ & & \\
\hline Worbarrow & $\begin{array}{l}\mathrm{A} \\
\mathrm{B}\end{array}$ & & $\begin{array}{l}23.5 \pm 1.62 b \\
28.1 \pm 6.68 b\end{array}$ & & $\begin{array}{l}10.6 \pm 1.53 \mathrm{a} \\
12.2 \pm 0.59 \mathrm{a}\end{array}$ \\
\hline Kimmeridge & $\begin{array}{l}\mathrm{A} \\
\mathrm{B} \\
\mathrm{C} \\
\mathrm{D} \\
\mathrm{E} \\
\mathrm{F} \\
\mathrm{G}\end{array}$ & $10.8 \pm 1.63 \mathrm{a}$ & $\begin{array}{l}20.8 \pm 1.48 \mathrm{~b} \\
31.2 \pm 3.93 \mathrm{~b}\end{array}$ & $\begin{array}{l}29.1 \pm 3.76 \mathrm{~b} \\
39.8 \pm 5.78 \mathrm{c} \\
58.1 \pm 2.94 \mathrm{c} \\
35.8 \pm 3.61 \mathrm{~b} \\
20.9 \pm 1.11 \mathrm{~b} \\
21.9 \pm 1.22 \mathrm{~b}\end{array}$ & $11.1 \pm 0.27 \mathrm{a}$ \\
\hline $\begin{array}{l}\text { St Aldhelm's } \\
\text { Head }\end{array}$ & $\begin{array}{l}\text { A } \\
\text { B } \\
\text { C } \\
\text { D }\end{array}$ & $\begin{array}{l}4.7 \pm 0.86 \\
7.9 \pm 1.05 \mathrm{a}\end{array}$ & & $\begin{array}{l}21.8 \pm 0.61 b \\
26.5 \pm 2.15 b\end{array}$ & $12.1 \pm 0.84 \mathrm{a}$ \\
\hline Winspit & $\begin{array}{l}\mathrm{A} \\
\mathrm{B}\end{array}$ & $\begin{array}{r}8.1 \pm 1.20 \mathrm{a} \\
11.9 \pm 1.38 \mathrm{a}\end{array}$ & & & $13.7 \pm 1.43 \mathrm{a}$ \\
\hline
\end{tabular}

Values followed by the same letter are not significantly different from each other $(t$-test, $P>0.05)$.

fore, the variation in indole glucosinolates appears to result from environmental effects, in contrast to the variation in aliphatic glucosinolates.

\section{Population differentiation at isozyme and glucosinolate control loci}

Three isozyme systems each provided a single polymorphic locus for analysis of the genetic structure of the Brassica populations. AcPH gave three zones of activity on acrylamide gels. Closest to the origin was a broad diffuse area of staining probably representing the overlapping products of several loci. The second zone gave sharp bands with apparently double- and single-banded phenotypes, however the staining intensity was too weak to allow reliable interpretation. The third zone (designated $\mathrm{AcPH}$ ) gave clear single- or triple-banded phenotypes and was interpreted as representing a single triallelic locus coding for a dimeric enzyme. This corresponds to a locus in cultivated Brassica (Wills \& Wiseman, 1980).

$\mathrm{ShDH}$ gave a single area of activity on acrylamide gels with single-, double- or triple-banded phenotypes. As ShDH codes for a monomeric enzyme (Weeden \& Wendel, 1989) the best explanation was that two loci were detected, the faster $S h D H^{2}$ being diallelic with two functional alleles, whilst the slower
$S h D H^{1}$ was diallelic with a single functional allele and a null allele. Only $S h D H^{2}$ is considered here.

PGI was resolved on starch gels and two zones of activity were obtained. The more anodal was monomorphic, but the other zone $\left(P G I^{1}\right)$ clearly represented the products of a triallelic locus coding for a dimeric enzyme. This is consistent with PGI in cultivated Brassica (for example Arus \& Orton, 1983).

The isozyme data were analysed by FSTAT to give an over all loci estimate of nonrandon mating within the populations $\left(F_{\text {IS }}\right)$. Table 4 shows $F_{\text {IS }}$ for each population and clearly demonstrates substantial inbreeding within the collection sites, especially at St Aldhelm's Head. Glucosinolate allele and genotype frequencies were estimated from null homozygote frequencies and corrected for inbreeding using the $F_{\text {Is }}$ estimate for the population in question (see Methods). The mean $F_{\text {Is }}$ estimate was used to calculate allele and genotype frequencies at Worbarrow.

The isozyme and glucosinolate genotype frequencies were then analysed to provide $F_{\mathrm{ST}}$ estimates over all populations at each locus separately, and over all glucosinolate and isozyme loci (Table 4). Each isozyme locus $F_{\mathrm{ST}}$ value and the over all isozyme loci $F_{\mathrm{ST}}$ estimate gave nonsignificant $F_{\mathrm{ST}}$ values over all populations. In contrast, glucosinolate loci, gave significant values for $F_{\mathrm{ST}}$, along with 
Table 4 Allele frequencies in Brassica oleracea at isozyme and glucosinolate loci

\begin{tabular}{|c|c|c|c|c|c|c|}
\hline \multirow[b]{2}{*}{ Locus } & \multirow[b]{2}{*}{ Allele } & \multicolumn{4}{|c|}{ Allele frequency } & \multirow[b]{2}{*}{$\begin{array}{r}F_{\mathrm{ST}} \pm \mathrm{SE} \text { over } \\
\text { all populations }\end{array}$} \\
\hline & & $\begin{array}{l}\text { Worbarrow } \\
I=0 G=18\end{array}$ & $\begin{array}{c}\text { Kimmeridge } \\
I=60 G=73\end{array}$ & $\begin{array}{c}\text { St Aldhelm's } \\
I=120 G=33\end{array}$ & $\begin{array}{c}\text { Winspit } \\
I=120 G=18\end{array}$ & \\
\hline$A c P H^{3}$ & $\begin{array}{l}a \\
b \\
c\end{array}$ & & $\begin{array}{l}0.132 \\
0.781 \\
0.088\end{array}$ & $\begin{array}{l}0.129 \\
0.663 \\
0.208\end{array}$ & $\begin{array}{l}0.096 \\
0.658 \\
0.246\end{array}$ & $0.012 \pm 0.013$ \\
\hline$P G I^{1}$ & $\begin{array}{l}a \\
b \\
c\end{array}$ & & $\begin{array}{l}0.500 \\
0.233 \\
0.267\end{array}$ & $\begin{array}{l}0.471 \\
0.413 \\
0.117\end{array}$ & $\begin{array}{l}0.148 \\
0.585 \\
0.267\end{array}$ & $0.109 \pm 0.044$ \\
\hline$S h D H^{2}$ & $\begin{array}{l}a \\
b\end{array}$ & & $\begin{array}{l}0.042 \\
0.958\end{array}$ & $\begin{array}{l}0.054 \\
0.946\end{array}$ & $\begin{array}{l}0.075 \\
0.925\end{array}$ & $0.000 \pm 0.002$ \\
\hline pro & $\begin{array}{l}+ \\
-\end{array}$ & $\begin{array}{l}1.00 \\
0.00\end{array}$ & $\begin{array}{l}1.00 \\
0.00\end{array}$ & $\begin{array}{l}0.12 \\
0.88\end{array}$ & $\begin{array}{l}0.25 \\
0.75\end{array}$ & $0.850 \pm 0.069^{* *}$ \\
\hline elong & $\begin{array}{l}+ \\
-\end{array}$ & $\begin{array}{l}1.00 \\
0.00\end{array}$ & $\begin{array}{l}0.75 \\
0.25\end{array}$ & $\begin{array}{l}1.00 \\
0.00\end{array}$ & $\begin{array}{l}1.00 \\
0.00\end{array}$ & $0.188 \pm 0.045^{*}$ \\
\hline alk & $\begin{array}{l}+ \\
-\end{array}$ & $\begin{array}{l}0.44 \\
0.56\end{array}$ & $\begin{array}{l}0.38 \\
0.62\end{array}$ & $\begin{array}{l}1.00 \\
0.00\end{array}$ & $\begin{array}{l}1.00 \\
0.00\end{array}$ & $0.469 \pm 0.083^{*}$ \\
\hline$o h$ & $\begin{array}{l}+ \\
-\end{array}$ & $\begin{array}{l}1.00 \\
0.00\end{array}$ & $\begin{array}{l}1.00 \\
0.00\end{array}$ & $\begin{array}{l}0.06 \\
0.94\end{array}$ & $\begin{array}{l}0.00 \\
1.00\end{array}$ & $0.960 \pm 0.028^{* * *}$ \\
\hline All isozyme loci & & & & & & $0.062 \pm 0.029$ \\
\hline All glucosinolate loci & & & & & & $0.705 \pm 0.076^{* * *}$ \\
\hline$F_{\text {Is }}$ over all isozyme loci & & & 0.105 & 0.412 & 0.248 & \\
\hline
\end{tabular}

For the glucosinolate loci, allele frequencies were estimated from the frequency of the null homozygous genotype (Table 2) and corrected for inbreeding with $F_{\text {Is }}$ for the appropriate population derived from the isozyme data.

The mean $F_{\text {Is }}$ was used to calculate allele frequencies at Worbarrow.

$I=$ number of plants used for isozyme analyses, $G=$ number of plants used for glucosinolate analyses.

Values of $F_{\mathrm{ST}}$ were tested against $F_{\mathrm{ST}}=0$ (the null hypothesis indicating no genetic differences between populations) with the use of a $t$-test: ${ }^{*} P=0.05-0.01 ;{ }^{* *} P=0.01-0.001 ;{ }^{* * *} P<0.001$.

Table 5 Pairwise $F_{\mathrm{ST}}$ estimates for isozyme and glucosinolate loci in the Brassica oleracea populations

\begin{tabular}{lccc}
\hline & \multicolumn{2}{c}{$F_{\mathrm{ST}}(\mathrm{mean} \pm \mathrm{SE})$} & \\
\cline { 2 - 3 } & Glucosinolate loci & Isozyme loci & $P\left(F_{\mathrm{ST}} \mathrm{I}=F_{\mathrm{ST}} \mathrm{G}\right)$ \\
\hline Winspit/St Aldhelm's & $0.004 \pm 0.008$ & $0.067 \pm 0.033$ & $>0.05$ \\
Winspit/Kimmeridge & $0.761 \pm 0.068^{* * *}$ & $0.122 \pm 0.040$ & $<0.001$ \\
Winspit/Worbarrow & $0.845 \pm 0.051^{* * *}$ & & $<0.001$ \\
St Aldhelm's/Kimmeridge & $0.771 \pm 0.045^{* * *}$ & $0.028 \pm 0.005^{*}$ & \\
St Aldhelm's/Worbarrow & $0.844 \pm 0.023^{* * *}$ & & \\
Kimmeridge/Worbarrow & $0.051 \pm 0.034$ & & \\
\hline
\end{tabular}

Values of $F_{\mathrm{ST}}$ were tested against $F_{\mathrm{ST}}=0$ (the null hypothesis indicating no genetic differences between populations) with the use of $t$-tests: ${ }^{*} P=0.05-0.01 ;{ }^{* *} P=0.01-0.001 ;{ }^{* *} P<0.001$.

$F_{\mathrm{ST}}$ for isozymes $\left(F_{\mathrm{ST}} \mathrm{I}\right)$ was also tested against $F_{\mathrm{ST}}$ for glucosinolates $\left(F_{\mathrm{ST}} \mathrm{G}\right)$. 
the over all glucosinolate loci $F_{\mathrm{ST}}$ estimate. These results show that there is greater differentiation between the populations in terms of allele frequencies at glucosinolate loci than at isozyme loci. This is confirmed by the significant difference between the all isozyme loci and all glucosinolate loci $F_{\text {ST }}$ values $\left(t_{4}=7.90, P=0.01-0.001\right)$.

To investigate further the differentiation between the populations, $F_{\mathrm{ST}}$ values were obtained between all pairs of populations for isozyme and glucosinolate loci (Table 5). At the isozyme loci, $F_{\mathrm{ST}}$ is low between all pairs of populations and not significantly different from $F_{\mathrm{ST}}=0$, except for between St Aldhelm's Head and Kimmeridge $(0.01<P<0.05)$. At the glucosinolate loci, some values are large and highly significant, whereas others are low and not significant. Winspit and St Aldhelm's Head have very similar allele frequencies at all the glucosinolate loci (Table 4 ) and this is reflected in a low $F_{\text {ST }}$ value (Table 5). The isozyme $F_{\text {ST }}$ value is not significantly different from the glucosinolate $F_{\mathrm{ST}}$ value between these two populations. Likewise, $F_{\mathrm{ST}}$ for glucosinolates is low between Worbarrow and Kimmeridge. Highly significant $(P<0.001) F_{\mathrm{ST}}$ values are found for all other pairwise comparisons.

These results show that large differences in allele frequencies occur at loci which regulate the occurrence of particular glucosinolates, in contrast to alleles at isozyme loci. This suggests that the differences at the glucosinolate loci are not the product of founder effects or drift but are the result of differential selection occurring at Winspit and St Aldhelm's Head in comparison with Kimmeridge and Worbarrow

\section{Discussion}

Significant genetic differences occur between the populations in both the total levels of aliphatic glucosinolates and the ratio of individual aliphatic glucosinolates. The differences in indole glucosinolates did not have a genetic basis but were caused by seasonal and other environmental variation. Herbivores, pathogens and physical damage are known to induce indole glucosinolates (Koritsas et al., 1989, 1991; Doughty et al., 1991; Macfarlane Smith et al. 1991; Bodnaryk, 1992; Birch et al., 1994).

The genetic variation in aliphatic glucosinolates may have arisen by chance through a combination of founder effects and genetic drift. To test this hypothesis, isozyme data were analysed to provide an estimation of genetic differentiation between the populations at loci at which variation is assumed to be more or less neutral. The data indicate little dif- ferentiation between populations at isozyme loci (Tables 4 and 5), suggesting that founder effects and drift have played little if any part in the origin and maintenance of the variation in allele frequencies at the glucosinolate loci. Thus the most likely explanation for the differences is divergent selection in the different habitats leading to contrasting glucosinolate profiles.

Three factors suggest that herbivores may be important selective agents in these habitats. First, the importance of glucosinolates in mediating herbivore interactions has been documented (Chew, 1988; Louda \& Mole; 1991). Secondly, the variation in aliphatic glucosinolate content is within the range which would have a significant effect on these interactions with both specialist and generalist herbivores (Giamoustaris \& Mithen, 1995). Thirdly, herbivores are widely regarded as having significant effects on plant population dynamics. Differences in the frequencies and types of herbivores which lead to divergent selection may result from differences in the physical aspects of the habitats and the associated plant communities.

\section{The physical environment and herbivory}

The habitat at Kimmeridge (cliff face and exposed cliff top) suggests that generalist herbivores are likely to be less frequent that at St Aldhelm's Head and Winspit. Mammalian herbivores such as rabbits and other small rodents are not able to feed on plants growing on the near-vertical cliff face, and there is likely to be few molluscs at this site. Seedlings establish in small rocky ledges in the cliff face directly into the shale and are exposed to salt spray from the sea and frequent subsidence. Plants growing on the top edge of the cliff are exposed to high winds and salt spray. Protection against generalist herbivores may thus not be required as they are unlikely to be important factors in this environment. In contrast, plants at St Aldhelm's Head and Winspit are found in relatively sheltered grassland. Seedlings establish in dense grass, in contrast to those at Kimmeridge. It is likely that small rodents, rabbits and molluscs are major herbivores in this habitat and relatively more important than insects, as recently demonstrated for another temperate grassland site (Hulme, 1994).

\section{Plant community composition, phytochemical associations and herbivory}

It is likely that the plant communities in which the $B$. oleracea plants are found, in addition to the 
physical environment, are important in determining the extent and nature of plant-herbivore interactions. At Kimmeridge, plants on the cliff top are closely associated with Rubus, Daucus carota and B. nigra, all of which may provide protection against generalist herbivores by making the plant community less attractive to opportunist grazers; Rubus providing physical protection against grazing by mammals and birds, and the secondary metabolites in $D$. carota (terpenes) and $B$. nigra (propenyl glucosinolate) making the plant community generally less palatable. Daucus carota is associated with wild $B$. oleracea populations at the majority of localities in the UK. Moreover, as the seedlings of both $B$. nigra and $B$. oleracea are morphologically similar, some generalist herbivores may associate $B$. oleracea seedlings with the pungency of propenyl isothiocyanate from $B$. nigra seedlings. The additional defences against herbivores provided by other species in the plant communities are examples of plant defence guilds (Atsatt \& O'Dowd, 1976) and associational plant refugia (Pfister \& Hay, 1988).

In addition to deterring generalist herbivores, the abundance of $B$. nigra may result in the enhancement of the local population of Brassica specialist insects, which feed both on $B$. nigra and $B$. oleracea . It was noticeable in these populations that there was considerable herbivory on $B$. nigra by flea beetles, which can be attributed to its high levels of aliphatic glucosinolate (Table 1; Giamoustaris \& Mithen, 1995). The flea beetles were also observed to feed on $B$. oleracea. In commercial Canola production, flea beetles are a major cause of seedling death (Lamb et al., 1991), and may be important in determining seedling survival in the wild Brassica populations. Thus, this may result in additional selection in $B$. oleracea for individuals with low levels of aliphatic glucosinolates which would be less attractive to flea beetles and other specialist insects. The same selection pressures are likely to act upon $B$. nigra as $B$. oleracea, but there appears to be no genetic variation in $B$. nigra for alleles at the Gsl loci as all genotypes which have been studied have high levels of propenyl glucosinolates (R. Mithen, unpublished).

Selection by specialist insects may also explain the differences in frequencies of alleles at the Gsl loci (Table 2). It has been shown that the side chain structure of individual glucosinolates is important in mediating the interaction between crucifers and their specialist herbivores (Louda \& Mole, 1991). For example, Psylliodes chrysocephala and Delia floralis respond less to 2-hydroxy-3-butenyl glucosinolate than to 3-butenyl glucosinolate (Simmonds et al., 1994; Giamoustaris \& Mithen, 1995). Likewise,
Ceutorhynchus assimilis and $P$. chrysocephala are less responsive to 2-propenyl glucosinolate and 2-propenyl isothiocyanate than longer chain homologues (Blight et al., 1989; Bartlet et al., 1994). Insects may also respond differently to methylsulphinylalkyl glucosinolates compared to their alkenyl homologues, possibly because of the isothiocyanates being less volatile.

The variation observed between the different collecting sites at Worbarrow Tout may result from local variation in the abundance of herbivores, generalist herbivores being relatively more abundant in the long grassland on top of the Tout than on the steep sides of the Tout, in a similar manner to the variation between the St Aldhelm's and Kimmeridge sites. Results from the analysis of glasshouse-grown plants from Worbarrow suggest that there is considerable allelic variation for total glucosinolate at this site. This is possibly maintained by small-scale differences in selection pressures within the habitat, analogous to the manner in which differences between St Aldhelm's and Kimmeridge in glucosinolate content are maintained by selection.

\section{Constraints on chemical coevolution}

In many habitats, selective pressure by generalist herbviores may prevent crucifers from escaping their insect herbivores through evolutionary changes in their secondary metabolites. Herbivory by insects may be an important selective factor in determining the levels and nature of plants' secondary metabolites only in particular habitats in which plants can physically escape from generalist herbivores, such as at Kimmeridge. However, other types of evolutionary changes may occur in the plant population as a response to selection pressure by insects. With regard to crucifer-insect interactions, there may be selection for a rapid life cycle, autogamy and large seed production at the expense of parental survival resulting in an 'inapparent' phenotype (sensu Feeny, 1976). This may explain how $B$. nigra is able to survive at Kimmeridge in spite of the heavy flea beetle population, and, in general, the relatively high frequency of taxa in the Brassicaceae which have rapid life histories, such as Arabidopsis, Capsella and Coronopus.

\section{Acknowledgements}

A. Giamoustaris thanks Cambridge Plant Breeders Ltd for financial support. The authors thank Ruth Magrath and Karen Jeal for technical assistance. 


\section{References}

ARUS, P. AND ORTON, T. J. 1983. Inheritance and linkage relationships of isozyme loci in Brassica oleracea. J. Hered., 74, 405-412.

ATSATT, P. R. AND O'DOWD, D. J. 1976. Plant defense guilds. Science, 193, 24-29.

BAILEy, N. J. T. 1959. Statistical Methods in Biology. English Universities Press, London.

BANO, F. 1993. Glucosinolates in Arabidopsis. PhD thesis, University of East Anglia, Norwich, UK.

BARTLET, E., PARSONS, D., WILliaMs, I. H. AND CLARK, S. J. 1994. The influence of glucosinolates and sugars on feeding by the cabbage stem flea beetle, Psylliodes chrysocephala. Entomologia exp. appl., 73, 77-83.

BIRCH, A. N. E., GRIFFITHS, D. W. AND MACFARLANE SMITH, w. H. 1990. Changes in forage and oilseed rape (Brassica napus) root glucosinolates in response to attack by turnip root fly (Delia floralis). J. Sci. Food Agric., 51, 309-320.

BLIGHT, M. M., PICKeTt, J. A., WADHAMS, L. J. AND WOODCOCK, C. M. 1989. Antennal responses of Ceutorhynchus assimilis and Psylliodes chrysocephala. In: Dale, M., Dewar, A., Froud-Williams, R. J., Hocking, T. J., Gareth Jones, D. and Rea, B. L. (eds) Aspects of Applied Biology, 23. Production and Protection of Oilseed rape and Other Brassica Crops, pp. 329-334. The Association of Applied Biologists, Wellesbourne, Warwick, U.K.

BODNARYK, R. R. 1992. Effects of wounding on glucosinolates in the cotyledons of oilseed rape and mustard. Phytochemistry, 31, 2671-2677.

CHEW, F. S. 1988. Biological effects of glucosinolates. In: Cutler, H.G. (ed) Biologically Active Natural Products Potential Use in Agriculture, pp. 155-181. American Chemical Society Symposium, Washington DC.

DOUGHTY, K. L., PORTER, A. J. L., MORTON, A. M., KIDDLE, G., BOCK, G. A. AND WALLSGROVE, R. 1991. Variation in glucosinolate content of oilseed rape (Brassica napus) leaves. II. Response to infection by Alternaria brassicae. Ann. appl. Biol., 118, 469-477.

FEENY, P. 1976. Plant apparency and chemical defense. Recent Adv. Phytochem., 10, 1-40.

GIAMOUSTARIS, A. AND MITHEN, R. F. 1995. Modifying the leaf glucosinolate content of oilseed rape and its effect on its interaction with specialist and generalist pests. Ann. Appl. Biol., 126, 347-363.

GLEN, D. M., JONES, H. AND FIELDSEND, J. K. 1990. Damage to oilseed rape seedlings by the field slug Deroceras reticulatum in relation to glucosinolate concentration. Ann. appl. Biol., 117, 197-207.

GOUDET, J. 1995. Fstat V-1.2: A computer program to calculate $F$-statistics. J. Hered., in press.

HICKs, K. L. 1974. Mustard oil glucosides: Feeding stimulants for adult cabbage stem flea beetles, Phyllotreta cruciferae. Ann. Entomol. Soc. Am., 67, 261-264.

HULME, P. E. 1994. Seedling herbivory in grassland: relative impact of vertebrate and invertebrate herbivores. $J$. Ecol., 82, 873-880.

KORITSAS, V. M., LEWIS, J. A. AND FENWICK, G. R. 1989.
Accumulation of indole glucosinolates in Psylliodes chrysocephala L.-infested or -damaged tissues of oilseed rape (Brassica napus L.). Experientia, 45, 493-495.

KORITSAS, V. M., LEWIS J. A. AND FENWICK, G. R. 1991. Glucosinolate responses of oilseed rape, mustard and kale to mechanical wounding and infestation by cabbage stem flea beetle (Psylliodes chrysocephala). Ann. appl. Biol., 118, 209-221.

LAMB, R. J., PALANISWAMY, P. AND BODNARKYK, R. P. 1991. Selection of oilseed rape with resistance to flea beetles. In: McGregor, D. I. (ed.) Proceedings of the Eighth International Rapeseed Congress, vol. 1, pp. 280-285. Groupe Consultatif International de Recherche sur le Colza and Canola Council of Canada, Saskatoon, Sask., Canada.

LOUDA, s. AND MOLE, s. 1991. Glucosinolates: Chemistry and ecology. In: Rosenthal, G. and Berenbaum, M. (eds.) Herbivores: Their Interactions with Secondary Plant Metabolites, vol. 1, The Chemical Participants, pp. 123-164. Academic Press, London.

MACFARLANE SMITH, W. H., GRIFFITHS, D. W. AND BOAG, B. 1991. Overwintering variation in glucosinolate content of green tissue of rape (Brassica napus) in response to grazing by wild rabbit (Oryctolagus cuniculus). J. Sci. Food Agric., 56, 511-521.

MAGRATH, R., HERRON, C., GIAMOUSTARIS, A. AND MITHEN, R. 1993. The inheritance of aliphatic glucosinolates in Brassica napus. Pl. Breed., 111, 55-72.

MAGRATH, R., MORGNER, M., BANO, F., PARKIN, I., SHARPE, A., LISTER, C., DEAN, C., TURNER, J., LYDIATE, D. AND MITHEN, R. 1994. Genetics of aliphatic glucosinolates. I. Side chain elongation in Brassica napus and Arabidopsis thaliana. Heredity, 72, 290-299.

MITCHELl, N. D. AND RICHARDS, A. J. 1979. Biological flora of the British Isles. No. 145. Brassica oleracea ssp. oleracea.J. Ecol., 66, 1087-1096.

MITHEN, R. 1992. Leaf glucosinolate profiles and their relationship to pest and disease resistance in oilseed rape. Euphytica, 63, 71-83.

MITHEN, R., LEWIS B. G. AND FENWICK, G. R. 1987. Glucosinolates in wild and cultivated Brassica species. Phytochemistry, 26, 1969-1973.

MITHEN, R., ClARKE, J., LISTER, C. AND DEAN, C. 1995. Genetics of aliphatic glucosinolates. III. Side chain structure of aliphatic glucosinolates in Arabidopsis thaliana. Heredity, 74, 210-215.

PARKIN, I., MAGRATH, R., KEITH, D., SHARPE, A., MITHEN, R. AND LYDIATE, D. 1994. Genetics of aliphatic glucosinolates II. Hydroxylation of alkenyl glucosinolates in Brassica napus. Heredity, 72, 594-598.

PFISTER, C. A. AND HAY, M. E. 1988. Associational plant refuges: convergent patterns in marine and terrestrial communities result from differeing mechanisms. Oecologia, 77, 118-129.

RAYBOULD, A. F., GRAY, A. J., LAWRENCE, M. J. AND MARSHALL, D. F. 1991. The evolution of Spartina anglica (Gramineae): origin and genetic variation. Biol. J. Linn. Soc., 43, 111-126.

RODMAN, J. E. 1980. Population variation and hybridiza- 
tion in sea-rockets (Cakile, Cruciferae): seed glucosinolate characters. Am. J. Bot., 67, 1145-1159.

RODMAN, J. E. AND CHEW, F. S. 1980. Phytochemical correlates of herbivory in a community of native and naturalised cruciferae. Biochem. Syst. Ecol., 8, 43-50.

SIMMONDS, M. S. J., BLANEY, W. M., MITHEN, R., BIRCH, A. N. E. AND LEWIS, J. 1994. Behavioural and chemosensory responses of the turnip root fly (Delia floralis) to glucosinolates. Entomologia exp. appl., 71, 45-57.

SNOGERUP, S., GUSTAFSSON, M. AND VON BOTHMER, R. 1990. Brassica sect. Brassica (Brassicaceae) 1. Taxonomy and variation. Willdenowia, 19, 271-365.

WEEDEN, N. F., AND WENDEL, J. F. 1989. Genetics of plant isozymes. In: Soltis, D. E. and Soltis, P. E. (eds) Isozymes in Plant Biology, pp. 46-72. Chapman \& Hall, London.
WEIR, B. S. AND COCKERHAM, C. C. 1984 . Estimating $F$ statistics for the analysis of population structure. Evolution, 38, 1358-1370.

WENDEL, J. F. AND WEEDEN, N. F. 1989. Visualisation and interpretation of plant isozymes. In: Soltis, D. E. and Soltis, P. E. (eds) Isozymes in Plant Biology, pp. 5-45. Chapman \& Hall, London.

WILls, A. B. AND WISEMAN, E. M. 1980. Acid phosphatase isoenzymes of Brassica oleracea seedlings and their application to sib testing in $\mathrm{F}_{1}$ hybrids. Ann. appl. Biol., 94, 137-142.

WRIGHT, s. 1921. Systems of mating, I-V. Genetics, 6, 111-178.

WRIGHT, s. 1943. Isolation by distance. Genetics, 28, 114-138. 